Running head: Attitudes to sex doll ownership

\title{
Attitudes toward sex doll ownership: Scale development and preliminary validation
}

\author{
Craig A. Harper ${ }^{1}$ \\ Rebecca Lievesley ${ }^{1}$ \\ Ellie Woodward ${ }^{1}$ \\ Roanna Wilson ${ }^{1,2}$ \\ Lauren Stubbs ${ }^{1}$
}

\footnotetext{
${ }^{1}$ NTU Psychology, School of Social Sciences, Nottingham Trent University (UK)

${ }^{2}$ Forensic Psychology Practice Ltd. (UK)
}

Correspondence concerning this article should be addressed to:

Dr. Craig Harper

NTU Psychology, School of Social Sciences, Nottingham Trent University, 50 Shakespeare Street, Nottingham, NG1 5FQ, UK.

Tel.: +44 (0)115848 4718 .

Email: craigaharper19@gmail.com 


\begin{abstract}
Sex dolls are beginning to become more mainstream, both in the public's consciousness and in academic research. However, there is no current systematic examination of public attitudes toward sex dolls within the peer-reviewed literature, which represents a barrier to the efficient study on this topic. In this paper we report the development and initial validation of such a measure. Using an international public sample $(N=377)$ we found that public attitudes toward sex doll owners were underpinned by three factors: 'Acceptability of Doll Ownership', 'Doll Owners as Immoral', and 'Doll Owners as Dysfunctional'. Scores on each of these factors, which make up the Sex Doll Ownership Attitudes Scale (SDOAS), were predicted by participant sex, religiosity, permissive sexual attitudes, right-wing authoritarianism, and the endorsement of mora intuitions that favor personal liberty. We present a full form 66-item version of the SDOAS, as well as an 18-item short form which both possess strong psychometric properties. We highlight potential future uses of the
\end{abstract} SDOAS as this emerging field of study continues to rapidly grow.

Keywords: sex dolls; public attitudes; scale development; sexuality; authoritarianism 
Attitudes toward sex doll ownership: Scale development and preliminary validation

\section{Introduction}

Materials designed to imitate the human body for sexual purposes have existed in various forms for centuries (Ferguson, 2014). With synthetic technologies constantly developing, modern sex dolls are becoming more affordable, more realistic, and more customizable than ever before (Arafat \& Kar, 2021; Döring, 2020; Döring \& Pöschl, 2018). Subsequently, debates on the acceptability of ownership and the characteristics of owners are receiving increased attention in social, legal, and academic circles (Björkas \& Larsson, 2021; Harper \& Lievesley, 2020; Langcaster-James \& Bentley, 2018; Maras \& Shapiro, 2017). However, there is no current systematic examination of the attitudes of the public toward sex dolls within the peer-reviewed literature. In this paper we report the development and initial validation of a measure of such public attitudes, including a commentary on the structure of these views and their various psychological predictors.

\section{Social Debates about Sex Doll Ownership}

Social views about sex dolls and their owners have not been comprehensively studied within the empirical literature (Harper \& Lievesley, 2020), and so we must look toward the media, popular culture, and professional society reports as an indicator of prevailing opinions about doll ownership (Cheok et al., 2017). Existing publications regarding sex doll owners are overwhelmingly negative, highlighting numerous concerns relating to sexual aggression, offending behavior, and social withdrawal (Björkas \& Larsson, 2011; Cox-George \& Bewley, 2018; Danaher, 2017; Döring \& Pöschl, 2018; Eskens, 2017; Strikwerda, 2017). Concerns here surround the idea that doll ownership encourages the development and rehearsal of implicit theories that are supportive of sexual aggression (Polaschek \& Gannon, 2004; Polaschek \& Ward, 2004), including sexual objectification and entitlement (Danaher, 2017; Eskens, 2017; Puig, 2017), which may in turn result in violent behaviors being normalized in human-human sexual interactions (Bouffard, 2010; Brown \& Shelling, 2019). However, there is no evidence to suggest that there is a link between sexual aggression and sex doll ownership (for a review, see Harper \& Lievesley, 2020), and publications suggesting the opposite of this either ignore competing arguments (e.g., Brown \& Shelling, 2019), or explicitly argue from a moralistic legal perspective (e.g., Danaher, 2017; Eskens, 2017).

The provocative and hypersexual appearance of the majority of dolls and robots available on the mass market is also deemed to be controversial when looking to understand 
social attitudes (Oleksy \& Wnuk, 2021). With a large proportion of owners reporting that sexual gratification is a key motivator for ownership (Valverde, 2012), dolls are designed to stimulate arousal and satisfy the 'male gaze' (Ponterotto, 2016; Su et al., 2019). More specifically, dolls are often hyperfeminine and petite with symmetrical facial structures and hourglass figures (Puig, 2017). It has been claimed that ownership therefore contributes toward an unrealistic standard of beauty whilst promoting the sexual objectification of women (Shokri \& Asl, 2015). These arguments stem from the feminist stance, which argues that sex dolls implicitly reduce a woman's purpose to passively serving men's sexual desires (Ndonye, 2019), but ignore a competing view that such doll specifications might be related to evolutionarily driven consumer preferences (for a discussion of evolutionary explanations for consumer behavior, see Saad, 2017). Social attitudes to sex doll owners may nonetheless be tied to views about the potentially misogynistic nature of doll appearances, with those who have an ideological or moral opposition to the sexualization of the female body being more likely to express opposition to sex doll availability.

Child-like sex dolls pose the most pressing legal and ethical issue in this area of research (Chatterjee, 2020). The importation of dolls designed to represent children has resulted in criminal prosecutions in the UK (Strikwerda, 2017), while many jurisdictions have moved to legislate bans on the ownership of such dolls (for a list of such moves, see Prostasia Foundation, 2021). The social view that the ownership of child-like dolls acts as a gateway to child sexual abuse is reflected in various editorials and opinion pieces (Brown \& Shelling, 2019; Döring \& Pöschl, 2018; Maras \& Shapiro, 2017). This is further reinforced by the fact that many prosecuted owners have also been found to be in possession of child sexual exploitation material (Broadhurst, 2021), though the nature of such investigations make it difficult to establish a timeline of causes and effects. That is, it may be that some individuals own sex dolls and move on to child sexual exploitation material (the gateway hypothesis), or it may be that some individuals who use child sexual exploitation material purchase sex dolls as a means of stopping their criminal behavior and achieving sexual satisfaction without harming real children (the prevention hypothesis). Although this form of doll ownership may be seen to promote the sexualization of children (Danaher, 2017; Maras \& Shapiro, 2017), it has been suggested that child-like sex dolls could be used in sexual prevention efforts as a victimless sexual outlet (Brown \& Shelling, 2019; Cox-George \& Bewley, 2018; Rutkin, 2016). However, the association between child-like sex doll ownership, the stigmatized label of 'pedophilia', and potential gateways into child sexual abuse may play a role in social attitudes toward sex doll ownership. 


\section{Why Do We Need a Measure of Stigmatizing Attitudes to Sex Doll Ownership?}

With sex doll ownership being a controversial topic of growing importance both socially and legally (Björkas \& Larsson, 2021), a standardized measure of stigmatizing attitudes to sex doll ownership is a much-needed development if empirical research is to progress in line with such debates (Harper \& Lievesley, 2020). This is because the standardization of the measurement of these attitudes can help us, as a field, to uniformly agree on the most appropriate conceptualization of attitudes toward this group and to avoid the temptation to frame our research questions and design our study materials in line with our a priori views and ideological positions.

Although preliminary studies have begun to suggest that gender, age, and religion may influence views toward sex doll owners (Appel et al., 2019; Eichenberg et al., 2019; Knox et al., 2017), more comprehensive research is needed to establish the multifactorial nature of such attitudes in the general population. This includes going beyond single-item indices of attitudes or ownership desires, and involves an evaluation of the structure of attitudes toward doll ownership in terms of their underlying themes and predictors. Further, negative social attitudes could prevent these advances from being explored further in empirical research (Döring et al., 2020). This is despite the argument that sex dolls could positively contribute toward the user's sexual fulfilment and quality of life (Valverde, 2012), and the possibility that dolls could be used in therapeutic settings with people who cannot have meaningful or fulfilling sexual experiences with living partners (Chatterjee, 2020; Eichenberg et al., 2019; Forsch-Villaronga \& Poulsen, 2020; Morgan, 2009). As the acceptability of ownership is a potential barrier to the wider use of sex dolls (either as general tools for sexual satisfaction, or in therapeutic settings), increasing our knowledge of stigmatizing attitudes could have real benefits in relation to public education and social messaging about doll ownership. As such, developing a valid and reliable tool for measuring social attitudes toward sex doll ownership is a vital first step in developing this area of research. It is this first step that is taken in the current paper.

\section{Methods}

\section{Participants}

We set out to recruit a minimum of 300 participants to be able to confidently conduct a factor analysis of our draft attitudes scale (Tabachnick \& Fidell, 2007). In total, 575 participants clicked on our survey link, which was advertised widely on various community pages on social media sites (e.g., Facebook) and online forums related to sex and 
relationships (e.g., via Reddit). Throughout our recruitment we sought to make use of nonprofessional social networks so as to not bias the data with an excessively educated sample. That is, although we do not purport to have recruited a representative community sample, we endeavored to recruit participants from different social groups.

Of these 575 people, 18 did not provide informed consent and were immediately screened out of the survey, and 90 gave their informed consent but completed nothing else within the survey. We made the decision to retain as many people within the sample as possible on the basis of their degree of engagement with our draft attitudes scale. In doing so, we set an arbitrary minimum of $50 \%$ completion of this measure. In total, 86 participants provided no responses to the draft scale (i.e., they provided their demographic information and then nothing else), while four participants completed less than half of the scale. As such, these 90 participants were removed from the dataset. This left 377 participants in the sample (124 men, 246 women, 7 'other'; $M_{\text {age }}=25.39$ years, $S D=9.24$ ).

Of these 377 participants, 202 participants were in a relationship (53.6\%) and 175 were not $(46.4 \%)$. The majority of participants identified as heterosexual $(n=257 ; 68.2 \%)$ or bisexual $(n=79 ; 21.0 \%)$. Minorities said that they were homosexual $(n=24 ; 6.4 \%)$ or had another sexual orientation $(n=17 ; 4.5 \%)$. Politically, most participants were either 'leftwing' or 'center-left' $(n=241 ; 63.9 \%)$. Smaller numbers said that they were a 'centrist' $(n=$ $86 ; 22.8 \%)$, or either 'center-right' or 'right-wing' ( $n=50 ; 13.2 \%)$. Most participants were 'not at all religious' $(n=233 ; 61.8 \%)$. The remainder of the sample said that they were 'a little bit' $(n=80 ; 21.2 \%)$, 'somewhat' $(n=26 ; 6.9 \%)$, 'moderately' $(n=26 ; 6.9 \%)$, or 'very' $(n=12 ; 3.2 \%)$ religious.

Only 12 of our participants (3.5\%) owned a sex doll at the time of data collection, while another 35 participants $(10.2 \%)$ said that they would like to. The remaining 296 participants $(86.3 \%)$ did not own a sex doll, nor did they express interest in doing so.

\section{Materials}

Demographics. Participants were asked to provide information about their sex (male / female / other), age (in years), location (country), relationship status (in a relationship / not in a relationship), and sexual orientation (heterosexual / homosexual / bisexual / other). We also asked participants to state their political orientation using a five-point scale anchored from 1 (left-wing) to 5 (right-wing), and their level of religiosity using a five-point scale anchored from 1 (not at all religious) to 5 (very religious). Participants also reported whether they currently owned a sex doll (yes / no but interested / no and not interested). 
Sex Doll Ownership Attitudes Scale. We developed a long list of 80 potential items for our Sex Doll Ownership Attitudes Scale (SDOAS). To do this, we surveyed the literature on attitudes and stigmatization toward sexual minorities, mental illness, and individuals with sexual convictions, and adapted items from existing measures. Measures that we used as inspiration during this process of developing items included the Attitudes to Sex Offenders Scale (Hogue, 1993; Hogue \& Harper, 2019), the Attitudes about Sadomasochism Scale (Yost, 2010), the Attitudes toward Transgendered Individuals Scale (Walch et al., 2012), and the Opinion about Mental Illness Scale (Cohen \& Struening, 1965). A fill list of the items on the draft SDOAS is presented in the factor analysis reported below (see Table 1). Each item was responded to using a six-point scale anchored from 1 ('strongly disagree') to 6 ('strongly agree'). The presentation order of the items was randomized for each participant to reduce the likelihood of order effects influencing the data.

Concurrent validity measures. In addition to conducting a factor analysis to identify the structure of attitudes toward sex doll owners, we wanted to explore potential predictors of these views. As such, we asked participants to complete a series of psychometric measures for us to be able to examine the concurrent validity of our developed scale.

Acknowledging that views about sex doll ownership might be reflective of broader attitudes about sex, we used Hendrick et al.'s (2006) Brief Sexual Attitudes Scale. This is a measure comprised of 23 items measuring sexual attitudes in four domains: permissiveness (characterized by tolerance of casual and premarital sex), birth control (characterized as endorsement of safe sex practices), communion (characterized as seeing sex as an important part of intimate relationships), and instrumentality (characterized as the view that sex is a biological imperative in isolation from committed relationships). In this study we did not include the 'birth control' factor due to its lack of theoretical links to the functions of sex doll ownership, and thus its lack of relevance to social attitudes. Each item was rated by participants using a five-point scale anchored from 1 ('strongly disagree') to 5 ('strongly agree). An average score for each factor was computed, with higher values indicating a greater level of endorsement of that factor. Each factor demonstrated acceptable internal consistency in this sample: permissiveness $\alpha=0.88$; communion $\alpha=0.77$; instrumentality $\alpha$ $=0.69$.

Considering that attitudes about sexuality can be driven by perceptions of traditionalism and an aggressive policing of traditions, we used Altemeyer's (1981) Right-Wing 
Authoritarianism Scale. This is a 22-item measure (e.g., "Women should have to promise to obey their husbands when they get married") with items rated using a nine-point scale anchored from 1 ('very strongly disagree') to 9 ('very strongly agree'). We computed an average score for each participant, with higher scores indicating more authoritarian beliefs. This measure demonstrated excellent levels of internal consistency in this sample $(\alpha=0.94)$.

Owing to common beliefs about the perceived role of sexism in sex doll ownership we included Swim et al.'s (1995) Modern Sexism Scale to measure subtle forms of discrimination (or ignorance of potential discrimination) toward women. This is an eight-item scale (e.g., "Society has reached the point where women and men have equal opportunities for achievement") with each item being scored using a five-point scale anchored from 1 ('strongly disagree') to 5 ('strongly agree'). We computed an average score across all items for each participant, with higher scores indicating more modern sexist attitudes. This measure demonstrated excellent levels of internal consistency in this sample $(\alpha=0.87)$.

It may also be the case that general moral intuitions - particularly with regard to care for minorities, following rules, and experiencing disgust - might affect views towards sex and, by extension, sex doll ownership. As such, we asked participants to complete the Moral Foundations Questionnaire (Graham et al., 2011). This is a 30-item questionnaire that asks participants to rate the relevance of various conditions when they are making a moral decision, and their agreement with various moral statements. Each item is rated on a six-point scale, and we calculated an average score for each of the five moral foundations measured by the scale: care/harm $(\alpha=0.56)$, fairness $(\alpha=0.57)$, ingroup loyalty $(\alpha=0.74)$, respect for authority $(\alpha=0.78)$, and purity $(\alpha=0.81)$. We also embedded the nine items used by Iyer et al. (2012) to measure 'liberty'-related moral intuitions into this questionnaire $(\alpha=0.72)$.

\section{Procedure}

Upon reading the general information about the survey in various advertisements on social media platforms, participants were able to click the link for fuller information. If they were happy to take part, they provided their informed consent before completing the demographic questionnaire. Following this, all participants first completed the draft SDOAS, before the additional measures were presented in a randomized order. Once all scales were complete, the survey software presented a comprehensive debriefing screen and provided researcher contact details and links for support, should these be needed. This procedure was reviewed and approved by the Nottingham Trent University School of Social Sciences Research Ethics Committee. 


\section{Results}

All analyses were run using the open-source jamovi software (v.2.2.5.0), which runs $R$ packages within a user-friendly graphical user interface. In this paper, all analyses used base $\mathrm{R}$ code (R Core Team, 2021) and the psych package (Revelle, 2019). Data and statistical output can be found at the project's Open Science Framework (OSF) page at https://osf.io/46bnk/.

\section{Exploratory Factor Analysis}

We ran an exploratory factor analysis (EFA) on all SDOAS items, extracting factors using the maximum likelihood method. The initial number of factors extracted was determined by parallel analysis, which runs simulations of the data. Factors with an observed eigenvalue that is above the $95^{\text {th }}$ percentile of the simulated eigenvalues are said to be statistically meaningful, and thus are extracted. This process led to four factors being identified.

In relation to the suitability of the data for factor analysis, the Kaiser-Meyer-Olkin coefficient, which has a range of 0-1, was 0.98 (and thus above the acceptable minimum threshold of 0.70; Hair et al., 2006). Bartlett's test of sphericity was also significant, $\chi^{2}(3081)$ $=30,0092, p<.001$. These results suggest that the data were suitable for factor analysis. We then explored the factors that were extracted with the view that we would retain factors that could be said to be psychometrically viable. That is, we set an arbitrary a priori minimum factor size of five items, all of which should make sense from a conceptual perspective once the directionality of their item loading was considered. The first three factors met these criteria, with no items loading meaningfully on to factor four (operationalized as a minimum factor loading of 0.40; Field, 2005). As such, we proceeded with a three-factor solution. Item loadings are presented in Table 1. 
Table 1. Item loadings within the exploratory factor analysis of the Sex Doll Ownership Attitudes Scale (SDOAS)

\begin{tabular}{|c|c|c|c|c|c|}
\hline \multirow[b]{2}{*}{ Item } & \multicolumn{4}{|c|}{ Factor } & \multirow[b]{2}{*}{ Uniqueness } \\
\hline & 1 & 2 & 3 & 4 & \\
\hline 77. I would support somebody who wanted to own a sex doll & 0.91 & -0.01 & 0.00 & -0.04 & 0.16 \\
\hline 76. Sex dolls should be normalized in our society & 0.89 & 0.13 & -0.10 & -0.12 & 0.20 \\
\hline 75. There are some positive uses of sex dolls & 0.83 & -0.05 & 0.13 & -0.07 & 0.38 \\
\hline 66. I would feel comfortable if I learned that my best friend owned a sex doll & 0.82 & 0.01 & -0.04 & 0.06 & 0.29 \\
\hline 74. We should be more supportive of people who own sex dolls & 0.80 & -0.04 & -0.03 & -0.12 & 0.24 \\
\hline 18. I would like associating with some people who own sex dolls & 0.80 & 0.02 & -0.05 & 0.07 & 0.33 \\
\hline $\begin{array}{l}\text { 67. I would feel uncomfortable if a close family member became romantically involved } \\
\text { with a someone who owned a sex doll }\end{array}$ & 0.77 & 0.00 & -0.09 & 0.17 & 0.30 \\
\hline 78. There is nothing wrong with people who own sex dolls & 0.75 & -0.09 & -0.10 & -0.01 & 0.20 \\
\hline 63. Sex doll ownership should be accepted completely into our society & 0.75 & -0.05 & -0.08 & -0.12 & 0.25 \\
\hline 72. There is nothing wrong with owning a sex doll & 0.74 & -0.18 & -0.05 & -0.06 & 0.15 \\
\hline $\begin{array}{l}\text { 64. I would feel comfortable working closely with somebody who I knew owned a sex } \\
\text { doll }\end{array}$ & 0.72 & -0.13 & -0.04 & 0.02 & 0.29 \\
\hline $\begin{array}{l}\text { 65. I would think no differently about my neighbour if I learned that they owned a sex } \\
\text { doll }\end{array}$ & 0.72 & 0.03 & -0.11 & 0.09 & 0.39 \\
\hline 73. Society's negative response to sex doll owners is wrong & 0.67 & -0.07 & -0.15 & -0.18 & 0.22 \\
\hline 13. I would never want one of my children dating somebody who owns a sex doll & -0.62 & 0.13 & 0.13 & -0.14 & 0.33 \\
\hline 43. I have respect for people who own sex dolls & 0.62 & -0.12 & -0.08 & -0.11 & 0.37 \\
\hline 4. I think I would like lot of people who own sex dolls & 0.54 & 0.03 & -0.17 & -0.05 & 0.56 \\
\hline 10. I wouldn't mind living next door to somebody who owns a sex doll & 0.54 & -0.34 & 0.02 & 0.09 & 0.39 \\
\hline $\begin{array}{l}\text { 56. If I was alone in a room with someone I knew to own a sex doll, I would feel } \\
\text { uncomfortable }\end{array}$ & -0.51 & 0.25 & 0.15 & 0.02 & 0.30 \\
\hline 35. People who own sex dolls are normal people, just like you and me & 0.50 & -0.06 & -0.35 & 0.10 & 0.29 \\
\hline 61. Owning a sex doll should be legal & 0.50 & -0.37 & 0.36 & 0.18 & 0.66 \\
\hline 32. People who own sex dolls could be trusted as babysitters & 0.47 & -0.16 & -0.14 & 0.08 & 0.50 \\
\hline
\end{tabular}


71. I am sure that sex doll owners could have effective relationships with other people

17. Some sex doll owners are pretty nice people

60. Many sex doll owners are very moral and ethical people

49. It is unfair to treat somebody differently because they own a sex doll

27. It is wrong to laugh about people who own sex dolls

7. People who own sex dolls are no better or worse than other people.

12. The values of most people who own sex dolls are about the same as the rest of us

41. We should harshly punish people who own sex dolls

25. Regardless of how you look at it, people who own sex dolls are no longer really human

16. In general, people who own sex dolls are basically bad people

54. Owning a sex doll should be against the law

15. Sex doll owners are just plain immoral

40. People who own sex dolls are cursed

47. People who own sex dolls are a danger to others

42. It is reasonable for a company to be allowed to fire somebody because they own a sex doll

11. Sex doll owners are horrible people

8 . You have to be constantly on your guard with people who own sex dolls

62. Sex doll owners are immoral

50. We should do all we can to stigmatize people who own sex dolls

9. Sex doll owners are selfish

2. Sex doll owners are really dangerous

23. People who own sex dolls should be prevented from having children

26. There is something about those who own sex dolls that makes it easy to tell them from normal people

53. Owning a sex doll is just plain wrong

58. People who own sex dolls are more likely to become involved in domestic violence

\begin{tabular}{ccccc}
$\mathbf{0 . 4 5}$ & -0.12 & -0.21 & 0.19 & 0.49 \\
$\mathbf{0 . 4 4}$ & -0.33 & -0.03 & 0.04 & 0.47 \\
$\mathbf{0 . 4 4}$ & -0.30 & -0.08 & 0.00 & 0.43 \\
$\mathbf{0 . 4 1}$ & -0.23 & -0.14 & -0.13 & 0.45 \\
0.36 & 0.09 & -0.18 & -0.32 & 0.66 \\
0.36 & -0.33 & -0.12 & 0.05 & 0.47 \\
0.30 & -0.17 & -0.30 & 0.01 & 0.52 \\
0.07 & $\mathbf{0 . 8 2}$ & -0.08 & 0.07 & 0.46 \\
0.14 & $\mathbf{0 . 8 1}$ & 0.04 & -0.16 & 0.44 \\
0.00 & $\mathbf{0 . 8 1}$ & 0.10 & -0.01 & 0.24 \\
-0.08 & $\mathbf{0 . 8 0}$ & -0.09 & 0.05 & 0.35 \\
-0.12 & $\mathbf{0 . 7 2}$ & 0.03 & 0.06 & 0.31 \\
-0.08 & $\mathbf{0 . 6 9}$ & -0.04 & 0.07 & 0.47 \\
-0.18 & $\mathbf{0 . 6 8}$ & 0.08 & -0.07 & 0.25 \\
0.04 & $\mathbf{0 . 6 4}$ & -0.01 & 0.09 & 0.62 \\
-0.08 & $\mathbf{0 . 6 3}$ & 0.15 & 0.04 & 0.36 \\
-0.19 & $\mathbf{0 . 6 0}$ & 0.14 & -0.10 & 0.28 \\
-0.22 & $\mathbf{0 . 5 9}$ & 0.06 & 0.21 & 0.25 \\
-0.12 & $\mathbf{0 . 5 8}$ & -0.03 & 0.17 & 0.52 \\
0.05 & $\mathbf{0 . 5 7}$ & 0.22 & 0.07 & 0.50 \\
-0.26 & $\mathbf{0 . 5 6}$ & 0.08 & -0.20 & 0.33 \\
-0.11 & $\mathbf{0 . 5 4}$ & 0.24 & 0.04 & 0.35 \\
0.17 & $\mathbf{0 . 5 1}$ & 0.31 & -0.10 & 0.62 \\
-0.34 & $\mathbf{0 . 4 9}$ & 0.11 & 0.17 & 0.21 \\
-0.16 & $\mathbf{0 . 4 9}$ & 0.21 & 0.01 & 0.41 \\
\hline & & & & \\
\hline
\end{tabular}


24. It is easy to recognize someone who owns a sex doll

59. A sex doll owner is more likely to rape a romantic partner than the average person 5. Most sex doll owners are stupid

48. Sex doll owners should be treated the same as anybody else

14. Most people who own sex dolls have the capacity for love

6. You never know when somebody who owns a sex doll is telling the truth

39. Sex doll owners are disgusting

44. I have no respect for people who own sex dolls

3. It is not wise to trust someone who owns a sex doll

38. People who own sex dolls should be ashamed of themselves

36. People who own sex dolls have emotional difficulties

45. Sex doll owners are mentally ill

68. People who own sex dolls are just sad people

57. Sex doll owners are rarely psychologically healthy

31. People who own sex dolls are mentally disturbed

28. People who own sex dolls are different to the rest of the population

29. To own a sex doll is to become a failure in life

79. Sex doll owners are abnormal

69. Sex doll owners are incapable of having normal relationships

37. Sex doll owners are perverts

52. Sex doll ownership is a perversion

34. Sex doll owners are just the same as anybody else

46. People who own sex dolls are perfectly healthy

21. Sex doll owners are normal people

1. Sex doll owners are different from most people

33. People who are successful do not own sex dolls

30. You would be foolish to marry a person who owns a sex doll

70. People who own sex dolls have generally been through bad break ups

$\begin{array}{ccccc}0.14 & \mathbf{0 . 4 7} & 0.29 & -0.11 & 0.67 \\ -0.16 & \mathbf{0 . 4 6} & 0.24 & 0.01 & 0.40 \\ -0.02 & \mathbf{0 . 4 5} & 0.33 & -0.01 & 0.48 \\ 0.35 & \mathbf{- 0 . 4 2} & -0.10 & -0.05 & 0.36 \\ 0.23 & \mathbf{- 0 . 4 1} & -0.11 & 0.19 & 0.53 \\ -0.12 & \mathbf{0 . 4 0} & 0.22 & -0.10 & 0.56 \\ -0.28 & \mathbf{0 . 4 0} & 0.28 & 0.17 & 0.20 \\ -0.25 & 0.39 & 0.20 & 0.21 & 0.35 \\ -0.36 & 0.38 & 0.17 & -0.01 & 0.32 \\ -0.25 & 0.35 & 0.33 & 0.29 & 0.18 \\ -0.02 & -0.07 & \mathbf{0 . 8 0} & -0.10 & 0.41 \\ 0.04 & 0.14 & \mathbf{0 . 7 9} & 0.02 & 0.25 \\ -0.10 & -0.03 & \mathbf{0 . 7 7} & 0.12 & 0.29 \\ -0.09 & 0.02 & \mathbf{0 . 7 5} & 0.10 & 0.28 \\ -0.05 & 0.21 & \mathbf{0 . 7 0} & 0.04 & 0.20 \\ -0.14 & 0.04 & \mathbf{0 . 6 4} & -0.14 & 0.40 \\ -0.11 & 0.15 & \mathbf{0 . 5 8} & 0.16 & 0.34 \\ -0.27 & 0.03 & \mathbf{0 . 5 6} & 0.10 & 0.32 \\ -0.18 & 0.11 & \mathbf{0 . 5 5} & -0.10 & 0.40 \\ -0.12 & 0.23 & \mathbf{0 . 5 4} & 0.22 & 0.26 \\ -0.12 & 0.25 & \mathbf{0 . 5 2} & 0.26 & 0.22 \\ 0.43 & -0.02 & -0.49 & 0.14 & 0.25 \\ 0.38 & -0.04 & \mathbf{- 0 . 4 9} & 0.02 & 0.29 \\ 0.38 & -0.04 & \mathbf{- 0 . 4 6} & 0.09 & 0.33 \\ -0.36 & -0.13 & \mathbf{0 . 4 6} & -0.18 & 0.53 \\ -0.23 & 0.06 & \mathbf{0 . 4 2} & -0.03 & 0.58 \\ -0.31 & 0.20 & \mathbf{0 . 4 0} & -0.03 & 0.33 \\ 0.11 & 0.10 & \mathbf{0 . 4 0} & -0.16 & 0.83\end{array}$


51. Sex doll owners just don't fit into our society

20. People who own sex dolls let their emotions control them

55. Owning a sex doll indicates that somebody has an inferior form of sexuality

19. Most people who own sex dolls have experiences relationship separation or divorce

final version of the scale. Item 68 loaded significantly on to the first factor but is framed in the opposite direction. This suggests a systematic misunderstanding of the item wording, and therefore the item was removed from the scale. Item 34 loaded onto two factors, and so was removed to improve the ease of scoring. 
Factor one was labelled 'Acceptability of Doll Ownership' and refers to general levels of support for the legal ownership of sex dolls. This factor was comprised of 26 items, such as "Sex dolls should be normalized in our society" and "Society's negative response to sex doll owners is wrong". Two of the 26 items were removed from the factor. The first was removed because it loaded in such a way as to be incompatible with the general theme of the factor ("I would feel uncomfortable if a close family member became romantically involved with a someone who owned a sex doll”, which depicts negativity about doll ownership but loaded positively onto the factor). The second removed item also loaded meaningfully on to factor three, and so was removed from both factors to maintain clear scoring procedures in the final version of the scale. This factor demonstrated excellent internal consistency, $\alpha=.97$ / $\omega=.97$. The average score on this factor was $4.14(S D=1.06)$, indicating moderately high levels of acceptance of sex doll ownership that were significantly above the scale mid-point, $t(371)=11.55, p<.001, d=0.60$.

Factor two was labelled "Doll Owners as Immoral" and measures the view that people who own sex dolls are immoral, dangerous, and deserving of punishment. There were 25 items that loaded meaningfully onto this factor, such as "Sex doll owners are just plain immoral" and "A sex doll owner is more likely to rape a romantic partner than the average person"). This factor demonstrated excellent internal consistency, $\alpha=.97 / \omega=.97$. The average score on this factor was $2.00(S D=0.79)$, which indicates low levels of immorality attributions about sex doll owners that were significantly below the scale mid-point, $t(372)=$ $-37.09, p<.001, d=-1.92$.

Factor three was labelled "Doll Owners as Dysfunctional" and reflects views that people who own sex dolls have mental health or personality difficulties. There were 18 items that loaded on to this factor, such as "People who own sex dolls have emotional difficulties" and "Sex doll owners are incapable of having normal relationships". As mentioned previously, one item was removed for also loading on to factor one ("Sex doll owners are just the same as anybody else"). This factor demonstrated excellent internal consistency, $\alpha=.96$ / $\omega=.96$. The average score on this factor was $2.69(S D=1.02)$, which indicates moderately low levels of attributions about personality disturbance among sex doll owners that were significantly below the scale mid-point, $t(372)=-15.33, p<.001, d=-0.79$.

\section{Between-Groups Differences}

We tested whether scores on each of the SDOAS factors differed as a function of various participant demographics. Descriptive statistics are presented in Table 2. 
On average, men scored higher than women in relation to the 'Acceptability of Doll Ownership' $t(363)=4.37, p<.001, d=0.48$. However, men scored lower than women on indices of seeing 'Doll Owners as Immoral', $t(364)=-5.25, p<.001, d=-0.58$, and 'Doll Owners as Dysfunctional', $t(364)=-2.50, p=.013, d=-0.28$. Scores on the SDOAS factors did not differ as a function of relationship status:

- 'Acceptability of Doll Ownership': $t(370)=0.11, p=.916, d=0.01$

- 'Doll Owners as Immoral': $t(371)=-0.44, p=.663, d=-0.05$

- 'Doll Owners as Dysfunctional': $t(371)=-0.21, p=.837, d=-0.02$

When exploring participants' self-reported sexual orientation, we found a small significant effect for 'Acceptability of Doll Ownership', $F(3,368)=3.48, p=.016, \eta^{2}=0.03$. This was attributable to bisexual participants scoring significantly higher than heterosexual participants, $M_{\text {difference }}=0.40, t(368)=2.97, p_{\text {tukey }}=.017, d=0.39$. No other pairwise comparisons were statistically significant. There was also a small significant effect in relation to seeing 'Doll Owners as Immoral', $F(3,369)=2.72, p=.044, \eta^{2}=0.02$. This effect was attributable to lower scores among bisexual participants in comparison to heterosexual participants, $M_{\text {difference }}=-0.27, t(369)=-2.64, p_{\text {tukey }}=.043, d=-0.34$. No other pairwise comparisons were statistically significant. There was no effect of sexual orientation on judgments of 'Doll Owners as Dysfunctional', $F(3,369)=0.92, p=.431, \eta^{2}=0.01$. 
Table 2. Descriptive statistics for SDOAS factor scores according to participant demographics

\begin{tabular}{|c|c|c|c|c|c|c|c|c|c|}
\hline \multirow[b]{3}{*}{ Variable } & \multicolumn{9}{|c|}{ SDOAS Factor } \\
\hline & \multicolumn{3}{|c|}{ Acceptability of Doll Ownership } & \multicolumn{3}{|c|}{ Doll Owners as Immoral } & \multicolumn{3}{|c|}{ Doll Owners as Dysfunctional } \\
\hline & $n$ & $M$ & $S D$ & $n$ & $M$ & $S D$ & $n$ & $M$ & $S D$ \\
\hline \multicolumn{10}{|l|}{ Sex } \\
\hline Male & 122 & 4.45 & 0.99 & 124 & 1.71 & 0.61 & 123 & 2.51 & 0.99 \\
\hline Female & 243 & 3.95 & 1.06 & 242 & 2.15 & 0.83 & 243 & 2.80 & 1.03 \\
\hline \multicolumn{10}{|l|}{ Relationship status } \\
\hline In a relationship & 202 & 4.13 & 1.01 & 201 & 1.98 & 0.73 & 201 & 2.68 & 1.03 \\
\hline Not in a relationship & 170 & 4.14 & 1.13 & 172 & 2.01 & 0.84 & 172 & 2.70 & 1.01 \\
\hline \multicolumn{10}{|l|}{ Sexual orientation } \\
\hline Heterosexual & 253 & 4.02 & 0.98 & 253 & 2.06 & 0.77 & 253 & 2.75 & 0.97 \\
\hline Homosexual & 24 & 4.13 & 1.32 & 24 & 2.06 & 0.94 & 24 & 2.66 & 1.09 \\
\hline Bisexual & 78 & 4.43 & 1.12 & 79 & 1.80 & 0.76 & 79 & 2.55 & 1.12 \\
\hline Other & 17 & 4.45 & 1.29 & 17 & 1.80 & 0.81 & 17 & 2.52 & 1.23 \\
\hline
\end{tabular}

Note. Data represent subsample sizes in each analysis, along with mean values and standard deviations by group. 


\section{Predicting Attitudes to Sex Doll Owners}

We ran a series of three linear regression analyses to separately predict scores on each of the three SDOAS factors. In these models, we entered sex (the 'Other' category was excluded here), age, relationship status, political orientation, and religiosity as demographic predictors, alongside the permissiveness, communion, and instrumentality subscales of the SAS, right-wing authoritarianism, modern sexism, and all six moral foundations. This led to models that included sixteen predictors. In line with analytic rules of thumb, we therefore required a sample of at least 178 participants (calculated as $50+8 m$, where $m$ represents the number of predictors; Tabachnick \& Fidell, 2007). Our sample is larger than this minimum figure. For information, zero-order correlations between our measured variables show how there is no collinearity within the models, although all SDOAS factors were highly correlated in the expected directions with each other (owing to the size of this Table, please see Table S1 of the supplementary materials on the project OSF page for these correlations; https://osf.io/46bnk/p). Regression coefficients for each model are presented in Tables 3a-c.

The model predicting the 'Acceptability of Doll Ownership' explained a significant proportion of the variance in scores on this SDOAS factor, adj. $R^{2}=.226, F(16,265)=6.14$, $p<.001$. Examining individual coefficients, women and those who score higher on rightwing authoritarianism were less likely than others to see the ownership of sex dolls as socially and ethically acceptable. In contrast, higher levels of acceptability were predicted by higher levels of religiosity, more permissive sexual attitudes, and more endorsement of the liberty foundation of morality.

The model predicting attitudes akin to 'Doll Owners as Immoral' explained a significant proportion of the variance in this outcome, adj. $R^{2}=.221, F(16,266)=6.01, p<$ .001 . Within the model, women and those who score higher on right-wing authoritarianism were more likely to see sex doll owners as immoral. On the other hand, lower immorality perceptions were predicted by higher levels of religiosity, more permissive sexual attitudes, and more endorsement of the liberty foundation of morality. These coefficients are inverse to those reported in relation to acceptability judgments.

The model predicting the view of 'Doll Owners as Dysfunctional' also explained a significant proportion of the variance in scores on this SDOAS factor, adj. $R^{2}=.102, F(16$, $267)=3.01, p<.001$. Examining individual coefficients, women and those who score higher on right-wing authoritarianism were more likely to see sex doll owners as psychologically and interpersonally dysfunctional. In contrast, lower perceptions of dysfunction were 
predicted by higher levels of religiosity and more endorsement of liberty-related moral intuitions.

Table 3a. Model coefficients predicting SDOAS Factor 1 scores ("Acceptability of Doll Ownership")

95\% CI ( $(\beta)$

\begin{tabular}{lccccccc} 
Predictor & $\boldsymbol{b}$ & $\boldsymbol{S} \boldsymbol{t}$ & $\boldsymbol{t}$ & $\boldsymbol{p}$ & $\boldsymbol{\beta}$ & Lower & Upper \\
& & & & & & & \\
\hline Intercept & 1.50 & 0.73 & 2.06 & .040 & & & \\
Sex & $\mathbf{- 0 . 3 1}$ & $\mathbf{0 . 1 4}$ & $\mathbf{- 2 . 2 7}$ & $\mathbf{. 0 2 4}$ & $\mathbf{- 0 . 3 0}$ & $\mathbf{- 0 . 5 5}$ & $\mathbf{- 0 . 0 4}$ \\
Age & 0.00 & 0.01 & 0.53 & .599 & 0.03 & -0.09 & 0.15 \\
Relationship & 0.07 & 0.12 & 0.60 & .553 & 0.07 & -0.16 & 0.30 \\
Politics & -0.02 & 0.07 & -0.28 & .782 & -0.02 & -0.15 & 0.12 \\
Religiosity & $\mathbf{0 . 1 5}$ & $\mathbf{0 . 0 6}$ & $\mathbf{2 . 4 2}$ & $\mathbf{. 0 1 6}$ & $\mathbf{0 . 1 5}$ & $\mathbf{0 . 0 3}$ & $\mathbf{0 . 2 6}$ \\
SAS Permissiveness & $\mathbf{0 . 2 9}$ & $\mathbf{0 . 0 8}$ & $\mathbf{3 . 4 1}$ & $<.001$ & $\mathbf{0 . 2 3}$ & $\mathbf{0 . 1 0}$ & $\mathbf{0 . 3 6}$ \\
SAS Communion & 0.08 & 0.08 & 1.04 & .298 & 0.06 & -0.06 & 0.18 \\
SAS Instrumentality & 0.09 & 0.08 & 1.15 & .251 & 0.07 & -0.05 & 0.18 \\
RWA & $\mathbf{- 0 . 1 8}$ & $\mathbf{0 . 0 8}$ & $\mathbf{- 2 . 2 7}$ & $\mathbf{. 0 2 4}$ & $\mathbf{- 0 . 2 1}$ & $\mathbf{- 0 . 4 0}$ & $\mathbf{- 0 . 0 3}$ \\
Modern Sexism & 0.07 & 0.08 & 0.81 & .421 & 0.06 & -0.08 & 0.19 \\
MFQ Harm & 0.12 & 0.11 & 1.09 & .276 & 0.08 & -0.06 & 0.22 \\
MFQ Fairness & -0.01 & 0.11 & -0.08 & .938 & -0.01 & -0.14 & 0.13 \\
MFQ Loyalty & 0.07 & 0.10 & 0.69 & .490 & 0.06 & -0.11 & 0.22 \\
MFQ Authority & -0.04 & 0.11 & -0.37 & .710 & -0.04 & -0.22 & 0.15 \\
MFQ Purity & -0.13 & 0.09 & -1.45 & .149 & -0.13 & -0.31 & 0.05 \\
MFQ Liberty & $\mathbf{0 . 2 8}$ & $\mathbf{0 . 0 8}$ & $\mathbf{3 . 4 1}$ & $<.001$ & $\mathbf{0 . 2 0}$ & $\mathbf{0 . 0 8}$ & $\mathbf{0 . 3 1}$
\end{tabular}

Note. 'Sex' refers to scores among female participants relative to male participants.

'Relationship' refers to scores among participants who were not in a relationship relative to those who were in a relationship. SAS = Sexual Attitudes Scale. RWA = Right-Wing Authoritarianism. MFQ $=$ Moral Foundations Questionnaire. $b$ refers to the unstandardized estimate, whereas $\beta$ refers to the standardized estimate. Significant predictors are presented in bold typeface. 
Table 3b. Model coefficients predicting SDOAS Factor 2 scores ("Doll Owners as Immoral")

$95 \%$ CI $(\beta)$

\begin{tabular}{lccccccc} 
Predictor & $\boldsymbol{b}$ & $\boldsymbol{S E}$ & $\boldsymbol{t}$ & $\boldsymbol{p}$ & $\boldsymbol{\beta}$ & Lower & Upper \\
& & & & & & & \\
\hline Intercept & 3.32 & 0.52 & 6.37 & $<.001$ & & & \\
Sex & $\mathbf{0 . 3 4}$ & $\mathbf{0 . 1 0}$ & $\mathbf{3 . 4 1}$ & $<. \mathbf{0 0 1}$ & $\mathbf{0 . 4 5}$ & $\mathbf{0 . 1 9}$ & $\mathbf{0 . 7 0}$ \\
Age & 0.00 & 0.01 & 0.24 & .808 & 0.02 & -0.11 & 0.13 \\
Relationship & 0.02 & 0.09 & 0.17 & .864 & 0.02 & -0.21 & 0.25 \\
Politics & -0.04 & 0.05 & -0.76 & .447 & -0.05 & -0.18 & 0.08 \\
Religiosity & $\mathbf{- 0 . 1 3}$ & $\mathbf{0 . 0 4}$ & $\mathbf{- 2 . 9 1}$ & $\mathbf{. 0 0 4}$ & $\mathbf{- 0 . 1 7}$ & $\mathbf{- 0 . 2 9}$ & $\mathbf{- 0 . 0 6}$ \\
SAS Permissiveness & $\mathbf{- 0 . 1 7}$ & $\mathbf{0 . 0 6}$ & $\mathbf{- 2 . 6 8}$ & $\mathbf{. 0 0 8}$ & $\mathbf{- 0 . 1 8}$ & $\mathbf{- 0 . 3 1}$ & $\mathbf{- 0 . 0 5}$ \\
SAS Communion & -0.02 & 0.06 & -0.39 & .698 & -0.02 & -0.14 & 0.10 \\
SAS Instrumentality & -0.02 & 0.06 & -0.33 & .745 & -0.02 & -0.14 & 0.10 \\
RWA & $\mathbf{0 . 1 8}$ & $\mathbf{0 . 0 6}$ & $\mathbf{3 . 2 3}$ & $\mathbf{. 0 0 1}$ & $\mathbf{0 . 3 0}$ & $\mathbf{0 . 1 2}$ & $\mathbf{0 . 4 9}$ \\
Modern Sexism & -0.03 & 0.06 & -0.55 & .585 & -0.04 & -0.18 & 0.10 \\
MFQ Harm & -0.03 & 0.08 & -0.38 & .703 & -0.03 & -0.17 & 0.11 \\
MFQ Fairness & -0.10 & 0.08 & -1.32 & .188 & -0.09 & -0.22 & 0.04 \\
MFQ Loyalty & -0.02 & 0.07 & -0.24 & .807 & -0.02 & -0.19 & 0.15 \\
MFQ Authority & -0.06 & 0.08 & -0.71 & .480 & -0.07 & -0.26 & 0.12 \\
MFQ Purity & 0.10 & 0.06 & 1.60 & .110 & 0.15 & -0.03 & 0.32 \\
MFQ Liberty & $\mathbf{- 0 . 1 3}$ & $\mathbf{0 . 0 6}$ & $\mathbf{- 2 . 1 0}$ & $\mathbf{. 0 3 7}$ & $\mathbf{- 0 . 1 2}$ & $\mathbf{- 0 . 2 4}$ & $\mathbf{- 0 . 0 1}$ \\
\hline
\end{tabular}

Note. 'Sex' refers to scores among female participants relative to male participants.

'Relationship' refers to scores among participants who were not in a relationship relative to those who were in a relationship. SAS = Sexual Attitudes Scale. RWA = Right-Wing Authoritarianism. MFQ $=$ Moral Foundations Questionnaire. $b$ refers to the unstandardized estimate, whereas $\beta$ refers to the standardized estimate. Significant predictors are presented in bold typeface. 
Table 3c. Model coefficients predicting SDOAS Factor 3 scores ("Doll Owners as Dysfunctional")

95\% CI ( $(\beta)$

\begin{tabular}{lccccccc} 
Predictor & $\boldsymbol{b}$ & $\boldsymbol{S} \boldsymbol{t}$ & $\boldsymbol{t}$ & $\boldsymbol{p}$ & $\boldsymbol{\beta}$ & Lower & Upper \\
\hline Intercept & 4.01 & 0.73 & 5.49 & $<.001$ & & & \\
Sex & $\mathbf{0 . 2 8}$ & $\mathbf{0 . 1 4}$ & $\mathbf{2 . 0 2}$ & $\mathbf{. 0 4 4}$ & $\mathbf{0 . 2 8}$ & $\mathbf{0 . 0 1}$ & $\mathbf{0 . 5 6}$ \\
Age & 0.00 & 0.01 & 0.17 & .866 & 0.01 & -0.12 & 0.14 \\
Relationship & -0.03 & 0.12 & -0.26 & .796 & -0.03 & -0.28 & 0.21 \\
Politics & -0.01 & 0.07 & -0.15 & .884 & -0.01 & -0.15 & 0.13 \\
Religiosity & $\mathbf{- 0 . 1 3}$ & $\mathbf{0 . 0 6}$ & $\mathbf{- 2 . 1 1}$ & $\mathbf{. 0 3 6}$ & $\mathbf{- 0 . 1 4}$ & $\mathbf{- 0 . 2 6}$ & $\mathbf{- 0 . 0 1}$ \\
SAS Permissiveness & -0.16 & 0.09 & -1.82 & .069 & -0.13 & -0.27 & 0.01 \\
SAS Communion & -0.07 & 0.08 & -0.85 & .395 & -0.06 & -0.18 & 0.07 \\
SAS Instrumentality & -0.14 & 0.08 & -1.75 & .081 & -0.11 & -0.23 & 0.01 \\
RWA & $\mathbf{0 . 1 7}$ & $\mathbf{0 . 0 8}$ & $\mathbf{2 . 0 8}$ & $\mathbf{. 0 3 8}$ & $\mathbf{0 . 2 1}$ & $\mathbf{0 . 0 1}$ & $\mathbf{0 . 4 1}$ \\
Modern Sexism & 0.11 & 0.09 & 1.32 & .187 & 0.10 & -0.05 & 0.25 \\
MFQ Harm & -0.03 & 0.11 & -0.25 & .807 & -0.02 & -0.17 & 0.13 \\
MFQ Fairness & 0.05 & 0.11 & 0.42 & .678 & 0.03 & -0.11 & 0.17 \\
MFQ Loyalty & -0.11 & 0.10 & -1.06 & .288 & -0.10 & -0.27 & 0.08 \\
MFQ Authority & 0.08 & 0.11 & 0.76 & .446 & 0.08 & -0.12 & 0.28 \\
MFQ Purity & 0.02 & 0.09 & 0.20 & .840 & 0.02 & -0.17 & 0.21 \\
MFQ Liberty & $\mathbf{- 0 . 2 2}$ & $\mathbf{0 . 0 9}$ & $\mathbf{- 2 . 5 9}$ & $\mathbf{. 0 1 0}$ & $\mathbf{- 0 . 1 6}$ & $\mathbf{- 0 . 2 9}$ & $\mathbf{- 0 . 0 4}$
\end{tabular}

Note. 'Sex' refers to scores among female participants relative to male participants.

'Relationship' refers to scores among participants who were not in a relationship relative to those who were in a relationship. SAS = Sexual Attitudes Scale. RWA = Right-Wing Authoritarianism. MFQ $=$ Moral Foundations Questionnaire. $b$ refers to the unstandardized estimate, whereas $\beta$ refers to the standardized estimate. Significant predictors are presented in bold typeface.

\section{A Short-Form of the SDOAS}

The full form of the SDOAS is comprised of 66 items, which is a long measure that might not be feasible for use by researchers with limited survey space. As such, we decided to formulate a short form of the measure, comprised of just 18 items. This shorter length was an arbitrary choice, designed to produce a coherent measure with six items per factor. We were informed by the guidance of Smith et al. (2000) when deciding upon the items to include in the short form version of the SDOAS. That is, we selected a range of higher- and lower-loading items, items with high item-total correlations, and items with a moderate average inter-item correlation. Tables $4 \mathrm{a}-\mathrm{c}$ report these statistics and the items retained in the short form of the SDOAS. 
Table 4a. Selection of items for the short form of the 'Acceptability of Doll Ownership' factor

\begin{tabular}{|c|c|c|c|}
\hline Item & Item loading & Item-total $r$ & Inter-item $r$ \\
\hline 77. I would support somebody who wanted to own a sex doll & 0.91 & 0.89 & 0.58 \\
\hline 76. Sex dolls should be normalized in our society & 0.89 & 0.85 & 0.56 \\
\hline 75. There are some positive uses of sex dolls & 0.83 & 0.76 & 0.50 \\
\hline 66. I would feel comfortable if I learned that my best friend owned a sex doll & 0.82 & 0.82 & $\mathbf{0 . 5 3}$ \\
\hline 74. We should be more supportive of people who own sex dolls & 0.80 & 0.85 & 0.56 \\
\hline 18. I would like associating with some people who own sex dolls & 0.80 & 0.80 & 0.51 \\
\hline 78. There is nothing wrong with people who own sex dolls & 0.75 & 0.88 & 0.57 \\
\hline 63. Sex doll ownership should be accepted completely into our society & 0.75 & 0.85 & 0.55 \\
\hline 72. There is nothing wrong with owning a sex doll & 0.74 & 0.90 & 0.58 \\
\hline 64. I would feel comfortable working closely with somebody who I knew owned a sex doll & 0.72 & 0.84 & 0.53 \\
\hline 65. I would think no differently about my neighbour if I learned that they owned a sex doll & 0.72 & 0.76 & 0.49 \\
\hline 73. Society's negative response to sex doll owners is wrong & 0.67 & 0.85 & 0.56 \\
\hline 13. I would never want one of my children dating somebody who owns a sex doll & -0.62 & -0.79 & -0.57 \\
\hline 43. I have respect for people who own sex dolls & 0.62 & 0.78 & 0.50 \\
\hline 4. I think I would like lot of people who own sex dolls & 0.54 & 0.64 & 0.42 \\
\hline 10. I wouldn't mind living next door to somebody who owns a sex doll & 0.54 & 0.76 & 0.48 \\
\hline 56. If I was alone in a room with someone I knew to own a sex doll, I would feel uncomfortable & -0.51 & -0.82 & -0.59 \\
\hline 35. People who own sex dolls are normal people, just like you and me & 0.50 & 0.79 & 0.52 \\
\hline 61. Owning a sex doll should be legal & 0.50 & 0.46 & 0.30 \\
\hline 32. People who own sex dolls could be trusted as babysitters & 0.47 & 0.69 & 0.45 \\
\hline 71. I am sure that sex doll owners could have effective relationships with other people & 0.45 & 0.67 & 0.44 \\
\hline 17. Some sex doll owners are pretty nice people & 0.44 & 0.71 & 0.47 \\
\hline 60. Many sex doll owners are very moral and ethical people & 0.44 & 0.74 & 0.49 \\
\hline 49. It is unfair to treat somebody differently because they own a sex doll & 0.41 & 0.71 & 0.47 \\
\hline
\end{tabular}

Note. Inter-item $r$ reflects the average inter-item correlation for each SDOAS item on the full form of the measure. Retained items are presented in bold typeface. 
Table 4b. Selection of items for the short form of the 'Doll Owners as Immoral' factor

\begin{tabular}{|c|c|c|c|}
\hline Item & Item loading & Item-total $r$ & Inter-item $r$ \\
\hline 41. We should harshly punish people who own sex dolls & 0.82 & 0.68 & 0.43 \\
\hline 25. Regardless of how you look at it, people who own sex dolls are no longer really human & 0.81 & 0.68 & 0.44 \\
\hline 16. In general, people who own sex dolls are basically bad people & 0.81 & 0.85 & -0.54 \\
\hline 54. Owning a sex doll should be against the law & 0.80 & 0.78 & 0.49 \\
\hline 15. Sex doll owners are just plain immoral & 0.72 & 0.81 & 0.51 \\
\hline 40. People who own sex dolls are cursed & 0.69 & 0.71 & 0.46 \\
\hline 47. People who own sex dolls are a danger to others & 0.68 & 0.85 & $\mathbf{0 . 5 3}$ \\
\hline 42. It is reasonable for a company to be allowed to fire somebody because they own a sex doll & 0.64 & 0.58 & 0.38 \\
\hline 11. Sex doll owners are horrible people & 0.63 & 0.79 & 0.50 \\
\hline 8. You have to be constantly on your guard with people who own sex dolls & 0.60 & 0.83 & 0.52 \\
\hline 62. Sex doll owners are immoral & 0.59 & 0.82 & 0.52 \\
\hline 50. We should do all we can to stigmatize people who own sex dolls & 0.58 & 0.65 & 0.41 \\
\hline 9. Sex doll owners are selfish & 0.57 & 0.69 & 0.44 \\
\hline 2. Sex doll owners are really dangerous & 0.56 & 0.77 & 0.48 \\
\hline 23. People who own sex dolls should be prevented from having children & 0.54 & 0.78 & 0.50 \\
\hline $\begin{array}{l}\text { 26. There is something about those who own sex dolls that makes it easy to tell them from } \\
\text { normal people }\end{array}$ & 0.51 & 0.58 & 0.38 \\
\hline 53. Owning a sex doll is just plain wrong & 0.49 & 0.85 & 0.53 \\
\hline 58. People who own sex dolls are more likely to become involved in domestic violence & 0.49 & 0.76 & 0.48 \\
\hline 24. It is easy to recognize someone who owns a sex doll & 0.47 & 0.55 & 0.35 \\
\hline 59. A sex doll owner is more likely to rape a romantic partner than the average person & 0.46 & 0.76 & 0.48 \\
\hline 5. Most sex doll owners are stupid & 0.45 & 0.70 & 0.45 \\
\hline 48. Sex doll owners should be treated the same as anybody else & -0.42 & 0.76 & -0.52 \\
\hline 14. Most people who own sex dolls have the capacity for love & -0.41 & 0.63 & -0.43 \\
\hline 6. You never know when somebody who owns a sex doll is telling the truth & 0.40 & 0.64 & 0.41 \\
\hline 39. Sex doll owners are disgusting & 0.40 & 0.84 & 0.52 \\
\hline
\end{tabular}

Note. Inter-item $r$ reflects the average inter-item correlation for each SDOAS item on the full form of the measure. Retained items are presented in bold typeface. 
Table 4c. Selection of items for the short form of the 'Doll Owners as Dysfunctional' factor

\begin{tabular}{|c|c|c|c|}
\hline Item & Item loading & Item-total $r$ & Inter-item $r$ \\
\hline 36. People who own sex dolls have emotional difficulties & 0.80 & 0.73 & 0.42 \\
\hline 45. Sex doll owners are mentally ill & 0.79 & 0.82 & 0.47 \\
\hline 68. People who own sex dolls are just sad people & 0.77 & 0.81 & 0.48 \\
\hline 57. Sex doll owners are rarely psychologically healthy & 0.75 & 0.82 & 0.47 \\
\hline 31. People who own sex dolls are mentally disturbed & 0.70 & 0.87 & 0.50 \\
\hline 28. People who own sex dolls are different to the rest of the population & 0.64 & 0.75 & 0.42 \\
\hline 29. To own a sex doll is to become a failure in life & 0.58 & 0.79 & 0.46 \\
\hline 79. Sex doll owners are abnormal & 0.56 & $\mathbf{0 . 8 0}$ & 0.45 \\
\hline 69. Sex doll owners are incapable of having normal relationships & 0.55 & 0.76 & 0.43 \\
\hline 37. Sex doll owners are perverts & 0.54 & $\mathbf{0 . 8 0}$ & 0.46 \\
\hline 52. Sex doll ownership is a perversion & 0.52 & 0.82 & 0.47 \\
\hline 46. People who own sex dolls are perfectly healthy & -0.49 & -0.82 & -0.55 \\
\hline 21. Sex doll owners are normal people & -0.46 & -0.77 & -0.52 \\
\hline 1. Sex doll owners are different from most people & 0.46 & 0.63 & 0.35 \\
\hline 33. People who are successful do not own sex dolls & 0.42 & 0.64 & 0.37 \\
\hline 30. You would be foolish to marry a person who owns a sex doll & 0.40 & 0.79 & -0.46 \\
\hline 70. People who own sex dolls have generally been through bad break ups & 0.40 & 0.36 & 0.21 \\
\hline
\end{tabular}

Note. Inter-item $r$ reflects the average inter-item correlation for each SDOAS item on the full form of the measure. Retained items are presented in bold typeface. 
As a check of the consistency of the full and short forms of the SDOAS we ran correlational analyses between scores on each version of the measure. As shown in Table 5, the pattern of correlations between the factors in the full and short forms is the same, and there is a high degree of concordance in the scores obtained for each factor irrespective of the version of the SDOAS. This demonstrates that both versions can be validly and reliably used to obtain the same average factor scores.

Table 5. Zero-order factor correlations within and between the full and short forms of the SDOAS

\begin{tabular}{lccc}
\hline & \multicolumn{3}{c}{ SDOAS short form } \\
\cline { 2 - 4 } SDOAS full form & Acceptability & Immorality & Dysfunction \\
\hline Acceptability & $0.97^{* * *}$ & $-0.82^{* * * *}$ & $-0.82^{* * *}$ \\
Immorality & $-0.86^{* * *}$ & $0.97^{* * *}$ & $0.81^{* * * *}$ \\
Dysfunction & $-0.87^{* * *}$ & $0.83^{* * *}$ & $0.97^{* * *}$ \\
\hline Short form $\alpha$ & 0.94 & 0.93 & 0.92 \\
\hline
\end{tabular}

Note. Data reflect Pearson's $r$ correlation coefficients. Figures across the diagonal (white cells) represent correlations between the two forms of the SDOAS. Figures in the shaded cells underneath the diagonal reflect inter-factor correlations within the full form of the SDOAS. Figures in the shaded cells above the diagonal reflect inter-factor correlations within the short form of the SDOAS.

*** $p<.001$

\section{Discussion}

In light of the growing social, legal, and academic interest in sex doll ownership (Harper \& Lievesley, 2020), in this paper we have developed a standardized measure of attitudes toward sex doll ownership, called the Sex Doll Ownership Attitudes Scale (SDOAS). In its complete form, this is a 66-item inventory of items, self-reported using a sixpoint scale, that measures views about the social acceptability of sex doll ownership, perceptions about the immorality of people who own sex dolls, and the extent to which people who own such dolls are seen as experiencing some degree of psychological or interpersonal dysfunction. We have also been able to construct equally valid and internally consistent short forms of these factors for use in research whereby survey space or project resourcing is limited.

The factorial nature of the SDOAS highlights how 'attitudes towards sex doll ownership' should not be considered a singular concept, but is instead comprised of three factors. The 'Acceptability of Doll Ownership' factor appears to be reflective of a permissive attitude about the legal availability of sex dolls, with items such as "Sex dolls should be 
normalized in our society" and "Society's negative response to sex doll owners is wrong" making up both the full and short forms of this factor. The 'Doll Owners as Immoral' factor reflects more negative attitudes that may be indicative of perceptions of sexual offending risk. This is best exemplified by items such as "People who own sex dolls are a danger to others" and "Sex doll owners are disgusting". The final factor of 'Doll Owners as Dysfunctional' is reflective of stigmatizing attributions made about the personalities and mental states of people who own sex dolls. For example, items on both the full and short forms include "Sex doll owners are mentally ill" and "Sex doll owners are perverts".

Broadly speaking, this factorial nature of the SDOAS is consistent with Breckler's (1984) tripartite model of attitudes. This framework suggests that attitudes possess an affective component (characterized as emotional responses to an attitude object; 'Doll Owners as Immoral'), a behavioral component (characterized as physical interactions or policy-related responses to an attitude object; 'Acceptability of Doll Ownership'), and a cognitive component (characterized as stereotypes and attributions made about an attitude object; 'Doll Owners as Dysfunctional'). This consistency with established frameworks provides further evidence of the theoretical validity of the SDOAS, and its fit with the broader attitudinal literature.

When exploring predictors of SDOAS we observed a similar trend in relation to each of the factors. That is, female participants and those who scored higher in relation to right-wing authoritarianism expressed more negative attitudes than men or those with less authoritarian beliefs. 'Negative attitudes' here acts as a stand in for lower scores in relation to judgments of the acceptability of sex dolls, and higher perceptions of owners' immorality and psychological dysfunction, given that these constructs significantly predicted all of these outcomes. There might be understandable reasons for such results, given the state of the current social and academic discourse around sex doll ownership. For example, if dolls are touted as articles that have the potential to objectify women and lead to sexual aggression (Bouffard, 2010; Brown \& Shelling, 2019; Danaher, 2017; Döring \& Pöschl, 2018; Eskens, 2017; Puig, 2017), then women might have more of an inherent motivation to view them (and their owners) as less desirable than men do, leading to a significant difference in judgments between the sexes (see also Olesky \& Wnuk, 2021). Further, the purported links between doll ownership and sexual deviance and aggression might lead those with authoritarian tendencies to desire for the banning of such materials, which is consistent with the sexually censorious nature of people with right-wing authoritarian belief structures (Falgares et al., 2021; Poteat $\&$ Mereish, 2012). 
In contrast, more positive views about doll ownership (i.e., higher levels of doll acceptability, and lower perceptions of owner immorality and dysfunction) were significantly predicted by a higher degree of religiosity, more permissive sexual attitudes, and a greater endorsement of individual liberty as a guiding moral principle. The only exception to this was in relation to sexual permissiveness not meeting the arbitrary threshold for significance in relation to perceptions of doll owners' levels of psychological or interpersonal dysfunction. These data are mixed in terms of their expectedness. That is, higher levels of religiosity being associated with more positive views about doll ownership is a surprise, given the historical trend of finding religious affiliation to be associated with more closed sexual attitudes and restricted sexual behaviors (e.g., Ahrold et al., 2011; Luquis et al., 2012). In one study on undergraduate attitudes toward sex dolls, religiosity was reported to be negatively associated with acceptability judgments (Knox et al., 2017), though no data were presented in the paper to corroborate this finding. There have been some studies to suggest that religiosity itself is less of a predictor of conservative sexual attitudes than religious engagement (i.e., regular attendance of formal religious services; see de Visser et al., 2007; Lefkowitz et al., 2004). We did not measure engagement with religious institutions, instead asking for a single-item rating of level of religiosity, which might be interpreted as anything from belief in an omnipotent God to identification with a religious group via a religious childhood context. However, the consistency of this finding is deserving of greater study to establish its precise nature.

The effects of sexual permissiveness and endorsing liberty-relation moral intuitions is much more straightforward to explain. That is, these constructs and associated behaviors are associated with openness to experiences and a freedom of expression (Ciocca et al., 2020; Clifford et al., 2015; Matthews et al., 2018) and have been linked to a range of non-partnered sexual experiences (e.g., higher rates of pornography use; Lam \& Chan, 2007). In this sense, finding more positive attitudes toward sex dolls (and less stigmatizing views about their owners) to be associated with permissive sexual attitudes and the endorsement of libertyrelated moral beliefs is to be expected, as individuals who endorse these views are likely to also hold the opinion that people should be allowed to engage in whatever sexual practices they like, so long as other individuals are not harmed. This might be reflective of the fact that the public are broadly aware of the primary sexual or masturbatory function of such dolls (Langcaster-James \& Bentley, 2018; Su et al., 2019; Valverde, 2012). However, our use of the label "sex dolls" in the SDOAS might also confound some of these findings, as it primes participants to consider the sexualized nature of doll ownership. 
Related to this point, it might therefore be interesting to explore whether adapting the 'sex doll' label might influence attitudes. For example, within the doll ownership community there is an emphasis on considering these materials as 'love dolls' or 'allodolls' (reflecting a humanoid doll that substitutes a relationship with others in a way that may, or may not, be sexual in nature; Langcaster-James \& Bentley, 2018). Conducting a comparison between scores on the SDOAS and a parallel version that re-frames the items with reference to 'love dolls' might ameliorate potential concerns over whether the SDOAS itself measures attitudes to dolls or to atypical sexual behavior in a broader sense.

We see the SDOAS as an individual difference measure, in that it can be used as a predictor of policy preferences in psychometric investigations, but it might also be amenable to change. As such, it could be fruitful to explore the effects of psychoeducation programs (possibly using narrative documentary films about doll owners) to explore whether attitudes toward dolls and their owners change as a function of receiving information about this population. It might also be that changes in attitudes also result in changes in policy preferences with regard to the commercial or clinical availability of dolls. We also suggest that the SDOAS might be used as a covariate in experimental studies of attitudes related to sex dolls. For example, if studies were investigating attitudes toward different types of dolls (e.g., static vs. dynamic dolls, or adult-like vs. child-like dolls), it would be prudent to control for baseline attitudes toward dolls in general in order to ensure that observed effects are due to the specific manipulations that are being made. The SDOAS represents a tool for achieving this aim.

In conclusion, we set out to create a standardized psychometric measure of attitudes toward sex doll ownership. In doing so, we have identified three underlying factors of such attitudes, reflecting views about the legal or social acceptability of doll ownership, the immorality and potential risks posed by owners, and their levels of psychological and interpersonal dysfunction. The SDOAS appears to be psychometrically sound, in that it possesses good internal consistency and scores are predicted by expected constructs. A full form and short form of the SDOAS are offered here for use in the broader literature (to access the scale, see https://osf.io/46bnk/) as this rapidly evolving subfield of sex science begins to explore the phenomenon of sex doll ownership in more systematic ways. 


\section{References}

Ahrold, T. K., Farmer, M., Trapnell, P. D., \& Meston, C. M. (2011). The relationship Among sexual attitudes, sexual fantasy, and religiosity. Archives of Sexual Behavior, 40, 619630. https://doi.org/10.1007/s10508-010-9621-4

Altemeyer, B. (1981). Right-wing authoritarianism. University of Manitoba Press.

Appel, M., Marker, C., \& Mara, M. (2019). Otakuism and the appeal of sex robots. Frontiers in Psychology, 10, 569. https://doi.org/10.3389/fpsyg.2019.00569

Arafat, S. Y., \& Kar, S. K. (2021). Sex during pandemic: Panic buying of sex toys during COVID-19 lockdown. Journal of Psychosexual Health, 3(2), 175-177. https://doi.org/10.1177/26318318211013347

Björkas, R., \& Larsson, M. (2021). Sex dolls in the Swedish media discourse: Intimacy, sexuality, and technology. Sexuality \& Culture, 25, 1227-1248. https://doi.org/10.1007/s12119-021-09829-6

Bouffard, L. A. (2010). Exploring the utility of entitlement in understanding sexual aggression. Journal of Criminal Justice, 38(5), 870-879. https://doi.org/10.1016/j.jcrimjus.2010.06.002

Breckler, S. J. (1984). Empirical validation of affect, behavior, and cognition as distinct components of attitude. Journal of Personality and Social Psychology, 47(6), 11911205. https://doi.org/10.1037/0022-3514.47.6.1191

Broadhurst, R. (2021). Child sex abuse images and exploitation materials. In R. Leukfeldt \& T. Holt (Eds.), The human factor of cybercrime (pp. 310-335). Routledge.

Brown, R., \& Shelling, J. (2019). Exploring the implications of child sex dolls. Australian Institute of Criminology. [https://www.aic.gov.au/publications/tandi/tandi570]

Chatterjee, B. B. (2020). Child sex dolls and robots: Challenging the boundaries of the child protection framework. International Review of Law, Computers \& Technology, 34(1), 22-43. https://doi.org/10.1080/13600869.2019.1600870

Cheok, A. D., Devlin, K., \& Levy, D. (2017). Love and sex with robots. Springer.

Cheok, A. D., \& Zhang, E. Y. (2019). Human-robot intimate relationships. Springer.

Ciocca, G., Robilotta, A., Fontanesi, L., Sansone, A., D'Antuono, L., Limoncin, E., Nimbi, F., Simonello, C., Di Lorenzo, G., Siracusano, A., \& Jannini, E. A. (2020). Sexological aspects related to Tinder use: A comprehensive review of the literature. Sexual Medicine Reviews, 8(3), 367-378. https://doi.org/10.1016/j.sxmr.2019.12.004

Clifford, S., Iyengar, V., Cabeza, R., \& Sinnott-Armstrong, W. (2015). Moral foundations vignettes: A standardized stimulus database of scenarios based on moral foundations 
theory. Behavior Research Methods, 47(4), 1178-1198. https://doi.org/10.3758/s13428014-0551-2

Cohen, J., \& Struening, E. L. (1965). Opinions about mental illness: Hospital differences in attitude for eight occupation groups. Psychological Reports, 17(1), 25-26. https://doi.org/10.2466/pr0.1965.17.1.25

Cox-George, C., \& Bewley, S. (2018). I, sex robot: The health implications of the sex robot industry. BMJ Sexual \& Reproductive Health, 44(3), 161-164. http://doi.org/10.1136/bmjsrh-2017-200012

Danaher, J. (2017). Robotic rape and robotic child sexual abuse: Should they be criminalised? Criminal Law and Philosophy, 11(1), 71-95. https://doi.org/10.1007/s11572-014-9362$\mathrm{X}$

de Visser, R. O., Smith, A. M. A., Richters, J., \& Rissel, C. E. (2007). Associations between religiosity and sexuality in a representative sample of Australian adults. Archives of Sexual Behavior, 36, 33-46. https://doi.org/10.1007/s10508-006-9056-0

Döring, N. (2020). How is the COVID-19 pandemic affecting our sexualities? An overview of the current media narratives and research hypotheses. Archives of Sexual Behavior, 49(8), 2765-2778. https://doi.org/10.1007/s10508-020-01790-z

Döring, N., \& Pöschl, S. (2018). Sex toys, sex dolls, sex robots: Our under-researched bedfellows. Sexologies, 27(3), e51-e55. https://doi.org/10.1016/j.sexol.2018.05.009

Eichenberg, C., Khamis, M., \& Hübner, L. (2019). The attitudes of therapists and physicians on the use of sex robots in sexual therapy: Online survey and interview study. Journal of Medical Internet Research, 21(8), e13853. https://doi.org/10.2196/13853

Eskens, R. (2017). Is sex with robots rape? Journal of Practical Ethics, 5(2), 62-76.

Falgares, G., Manna, G., Costanzo, G., De Santis, S., Kopala-Sibley, D. C., \& Ingoglia, S. (2021). The predictive role of ideological, personality and psychopathological factors in homonegative attitudes in Italy. Sexuality \& Culture. Advance online publication. https://doi.org/10.1007/s12119-021-09894-X

Ferguson, A. (2014). The sex doll: A history. McFarland.

Field, A. (2005). Discovering statistics using SPSS (2nd ed.). Sage Publications, Inc.

Forsch-Villaronga, E., \& Poulsen, A. (2020). Sex care robots: Exploring the potential use of sexual robot technologies for disabled and elder care. Journal of Behavioral Robotics, 11(1), 1-18. https://doi.org/10.1515/pjbr-2020-0001 
Galaitsi, S. E., Hendren, C. O., Trump, B., \& Linkov, I. (2019). Sex robots: A harbinger for emerging AI risk. Frontiers in Artificial Intelligence, 2, e27. https://doi.org/10.3389/frai.2019.00027

Graham, J., Nosek, B. A., Haidt, J., Iyer, R., Koleva, S., \& Ditto, P. H. (2011). Mapping the moral domain. Journal of Personality and Social Psychology, 101(2), 366-385. https://doi.org/10.1037/a0021847

Hair, J. F., Black, W. C., Babin, B. J., Anderson, R. E., \& Tatham, R. L. (2006). Multivariate data analysis. Pearson University Press.

Harper, C. A., \& Lievesley, R. (2020). Sex doll ownership: An agenda for research. Current Psychiatry Reports, 22(10), e54. https://doi.org/10.1007/s 11920-020-01177-w

Hendrick, C., Hendrick, S. S., \& Reich, D. A. (2006) The brief sexual attitudes scale. The Journal of Sex Research, 43(1), 76-86. https://doi.org/10.1080/00224490609552301

Hogue, T. E. (1993). Attitudes towards prisoners and sexual offenders. Issues in Criminological \& Legal Psychology, 19, 27-32.

Hogue, T. E., \& Harper, C. A. (2019). Development of a 21-item short form of the Attitudes to Sexual Offenders (ATS) Scale. Law and Human Behavior, 43(1), 117-130. https://doi.org/10.1037/lhb0000308

Iyer, R., Koleva, S., Graham, J., Ditto, P., \& Haidt, J. (2012). Understanding libertarian morality: The psychological dispositions of self-identified libertarians. PLoS ONE, 7(8), e42366. https://doi.org/10.1371/journal.pone.0042366

Knox, D., Huff, S., \& Chang, I. J. (2017). Sex dolls-creepy or healthy? Attitudes of undergraduates. Journal of Positive Sexuality, 3(2), 32-37.

Lam, C. B., \& Chan, D. K. -S. (2007). The use of cyberpornography by young men in Hong Kong: Some psychosocial correlates. Archives of Sexual Behavior, 36, 588-598. https://doi.org/10.1007/s10508-006-9124-5

Langcaster-James, M., \& Bentley, G. R. (2018). Beyond the sex doll: Post-human companionship and the rise of the 'allodoll'. Robotics, 7(4), e62. https://doi.org/10.3390/robotics7040062

Lefkowitz, E. S., Gillen, M. M., Shearer, C. L., \& Boone, T. L. (2004). Religiosity, sexual behaviors, and sexual attitudes during emerging adulthood. The Journal of Sex Research, 41(2), 150-159. https://doi.org/10.1080/00224490409552223

Luquis, R. R., Brelsford, G. M., \& Rojas-Guy;er, L. (2012). Religiosity, spirituality, sexual attitudes, and sexual behaviors among college students. Journal of Religion and Health, 51, 601-614. https://doi.org/10.1007/s10943-011-9527-z 
Maras, M. H., \& Shapiro, L. R. (2017). Child sex dolls and robots: More than just an uncanny valley. Journal of Internet Law, 21(5), 3-21.

Matthews, S. J ., Giuliano, T. A ., Rosa, M. N ., Thomas, K. H ., Swift, B. A ., Ahearn, N. D., Garcia, A. G ., Smith, S. R ., Niblett, C. M ., \& Mills, M. M . (2018). The battle against bedroom boredom: Development and validation of a brief measure of sexual novelty in relationships. Canadian Journal of Human Sexuality, 27(3), 277-287. https://doi.org/10.3138/cjhs.2017-0041

Middleweek, B. (2021). Male homosocial bonds and perceptions of human-robot relationships in an online sex doll forum. Sexualities, 24(3), 370-387. https://doi.org/10.1177/1363460720932383

Moors, A. C., Selterman, D., \& Conley, T. D. (2017). Personality correlates of desire to engage in consensual non-monogamy among lesbian, gay, and bisexual individuals. Journal of Bisexuality, 4, 418-434. https://doi.org/10.1080/15299716.2017.1367982

Morgan, M. (2009). Using anatomical dolls in HIV/AIDS prevention programs. American Journal of Sexuality Education, 4(1), 28-39. https://doi.org/10.1080/15546120902733240

Ndonye, M. M. (2019). Mass-mediated feminist scholarship failure in Africa: Normalised body objectification as artificial intelligence (AI). Journal of Media and Communication Studies, 1(1), 1-8. https://doi.org/10.51317/ecjmcs.v1i1.47

Oleksy, T., \& Wnuk, A. (2021). Do women perceive sex robots as threatening? The role of political views and presenting the robot as a female-vs male-friendly product. Computers in Human Behavior, 117, e106664. https://doi.org/10.1016/j.chb.2020.106664

Polaschek, D. L. L., \& Gannon, T. A. (2004). The implicit theories of rapists: What convicted offenders tell us. Sexual Abuse, 16(4), 299-314. https://doi.org/10.1177/107906320401600404

Polaschek, D. L. L., \& Ward, T. (2002). The implicit theories of potential rapists: What our questionnaires tell us. Aggression and Violent Behavior, 7(4), 385-406. https://doi.org/10.1016/S1359-1789(01)00063-5

Ponterotto, D. (2016). Resisting the male gaze: Feminist responses to the "normatization" of the female body in Western culture. Journal of International Women's Studies, 17(1), 133-151. 
Poteat, V. P., \& Mereish, E. H. (2012). Ideology, prejudice, and attitudes toward sexual minority social policies and organizations. Political Psychology, 33(2), 211-224. https://doi.org/10.1111/j.1467-9221.2012.00871.x

Prostasia Foundation. (2021). Our campaigns against doll bans. Retrieved from https://prostasia.org/sex-doll-laws/

Puig, K. (2017). The synthetic hyper femme: On sex dolls, fembots, and the futures of sex [Unpublished master's thesis]. San Diego State University.

R Core Team (2021). R: A Language and environment for statistical computing. (Version 4.0) [Computer software]. Retrieved from https://cran.r-project.org. (R packages retrieved from MRAN snapshot 2021-04-01).

Revelle, W. (2019). psych: Procedures for psychological, psychometric, and personality research. [R package]. Retrieved from https://cran.r-project.org/package=psych.

Richards, R., Coss, C., \& Quinn, J. (2016). Exploration of relational factors and the likelihood of a sexual robotic experience. In A. D. Cheok, K. Devlin, \& D. Levy (Eds.), Love and sex with robots (pp. 97-103). Springer.

Ronen, S. (2021). Gendered morality in the sex toy market: Entitlements, reversals, and the irony of heterosexuality. Sexualities, 24(4), 614-635. https://doi.org/10.1177/1363460720914601

Rutkin, A. (2016). Could sex robots and virtual reality treat paedophilia? New Scientist. [https://www.newscientist.com/article/2099607-could-sex-robots-and-virtual-realitytreat-paedophilia/]

Saad, G. (2017). On the method of evolutionary psychology and its applicability to consumer research. Journal of Marketing Research, 54(3), 464-477. https://doi.org/10.1509/jmr.14.0645

Shokri, N., \& Asl, M. P. (2015). Patriarchal hierarchies of power and the subordination of women: Real doll as a replacement of woman figure. Advances in Language and Literary Studies, 6(4), 216-220.

Strikwerda, L. (2017). Legal and moral implications of child sex robots. In J. Danaher \& N. McArthur (Eds.), Robot sex: Social and ethical implications (pp. 133-152). MIT Press.

Su, N. M., Lazar, A., Bardzell, J., \& Bardzell, S. (2019). Of dolls and men: Anticipating sexual intimacy with robots. ACM Transactions on Computer-Human Interaction, 26(3), e13. https://doi.org/10.1145/3301422 
Swim, J. K., Aikin, K. J., Hall, W. S., \& Hunter, B. A. (1995). Sexism and racism: Oldfashioned and modern prejudices. Journal of Personality and Social Psychology, 68(2), 199-214. https://doi.org/10.1037/0022-3514.68.2.199

Tabachnick, B. G., \& Fidell, L. S. (2007). Using multivariate statistics (5th ed.). Allyn \& Bacon/Pearson Education.

Valverde, S. (2012). The modern sex doll owner: A descriptive analysis [Master's, California Polytechnic State University]. https://digitalcommons.calpoly.edu/theses/849

Walch, S. E., Ngamake, S. T., Francisco, J., Stitt, R. L., \& Shingler, K. A. (2012). The Attitudes Toward Transgendered Individuals Scale: Psychometric properties. Archives of Sexual Behavior, 41(5), 1283-1291. https://doi.org/10.1007/s10508-012-9995-6

Yost, M. R. (2010). Development and validation of the attitudes about sadomasochism scale. The Journal of Sex Research, 47(1), 79-91. https://doi.org/10.1080/00224490902999286 


\section{Appendix}

\section{Sex Doll Ownership Attitudes Scale (SDOAS)}

Response options:

\begin{tabular}{cccccc}
\hline $\mathbf{1}$ & $\mathbf{2}$ & $\mathbf{3}$ & $\mathbf{4}$ & $\mathbf{5}$ & $\mathbf{6}$ \\
\hline $\begin{array}{c}\text { Strongly } \\
\text { disagree }\end{array}$ & Disagree & $\begin{array}{c}\text { Somewhat } \\
\text { disagree }\end{array}$ & $\begin{array}{c}\text { Somewhat } \\
\text { agree }\end{array}$ & Agree & $\begin{array}{c}\text { Strongly } \\
\text { agree }\end{array}$ \\
\hline
\end{tabular}

\begin{tabular}{lll}
\hline Item & & Fact \\
\hline 1 & I would support somebody who wanted to own a sex doll & Acc \\
2 & Sex dolls should be normalized in our society \\
3 & There are some positive uses of sex dolls \\
4 & I would feel comfortable if I learned that my best friend & \\
& owned a sex doll \\
5 & We should be more supportive of people who own sex dolls \\
6 & I would like associating with some people who own sex dolls & Acc \\
7 & There is nothing wrong with people who own sex dolls & Acc \\
8 & Sex doll ownership should be accepted completely into our & society \\
9 & There is nothing wrong with owning a sex doll
\end{tabular}

10 I would feel comfortable working closely with somebody who I knew owned a sex doll

11 I would think no differently about my neighbour if I learned Acc that they owned a sex doll

12 Society's negative response to sex doll owners is wrong Acc Y (Item 6)

*13 I would never want one of my children dating somebody who Acc owns a sex doll

14 I have respect for people who own sex dolls

Acc

15 I think I would like lot of people who own sex dolls

Acc

16 I wouldn't mind living next door to somebody who owns a sex

Acc doll

*17 If I was alone in a room with someone I knew to own a sex

Acc doll, I would feel uncomfortable

18 People who own sex dolls are normal people, just like you and

Acc me

19 Owning a sex doll should be legal

Acc

20 People who own sex dolls could be trusted as babysitters Acc

21 I am sure that sex doll owners could have effective Acc relationships with other people

22 Some sex doll owners are pretty nice people Acc

23 Many sex doll owners are very moral and ethical people Acc

24 It is unfair to treat somebody differently because they own a Acc sex doll 
25 We should harshly punish people who own sex dolls Imm

26 Regardless of how you look at it, people who own sex dolls Imm are no longer really human

27 In general, people who own sex dolls are basically bad people Imm

28 Owning a sex doll should be against the law Imm

29 Sex doll owners are just plain immoral Imm

30 People who own sex dolls are cursed Imm

31 People who own sex dolls are a danger to others Imm

32 It is reasonable for a company to be allowed to fire somebody Imm because they own a sex doll

33 Sex doll owners are horrible people Imm

34 You have to be constantly on your guard with people who Imm Y (Item 9) own sex dolls

35 Sex doll owners are immoral Imm

36 We should do all we can to stigmatize people who own sex Imm dolls

37 Sex doll owners are selfish

Imm

38 Sex doll owners are really dangerous Imm

Y (Item 10)

39 People who own sex dolls should be prevented from having Imm children

40 There is something about those who own sex dolls that makes Imm it easy to tell them from normal people

41 Owning a sex doll is just plain wrong Imm

42 People who own sex dolls are more likely to become involved Imm in domestic violence

43 It is easy to recognize someone who owns a sex doll Imm

44 A sex doll owner is more likely to rape a romantic partner Imm than the average person

45 Most sex doll owners are stupid Imm

*46 Sex doll owners should be treated the same as anybody else Imm

*47 Most people who own sex dolls have the capacity for love Imm

48 You never know when somebody who owns a sex doll is Imm telling the truth

49 Sex doll owners are disgusting

$\operatorname{Imm} \quad \mathrm{Y}($ Item 12)

50 People who own sex dolls have emotional difficulties Dys

51 Sex doll owners are mentally ill Dys

Y (Item 11)

Y (Item 7)

Y (Item 8)

Y (Item 9)

52 People who own sex dolls are just sad people

Dys $\quad \mathrm{Y}($ Item 14)

53 Sex doll owners are rarely psychologically healthy Dys

54 People who own sex dolls are mentally disturbed Dys

55 People who own sex dolls are different to the rest of the Dys Y (Item 15) population 
56 To own a sex doll is to become a failure in life

Dys $\quad \mathrm{Y}($ Item 16)

57 Sex doll owners are abnormal

Dys Y (Item 17)

58 Sex doll owners are incapable of having normal relationships

Dys

59 Sex doll owners are perverts

Dys Y (Item 18)

60 Sex doll ownership is a perversion

Dys

*61 People who own sex dolls are perfectly healthy

Dys

*62 Sex doll owners are normal people

Dys

63 Sex doll owners are different from most people

Dys

64 People who are successful do not own sex dolls

Dys

65 You would be foolish to marry a person who owns a sex doll

Dys

66 People who own sex dolls have generally been through bad

Dys break ups

\section{Factor Key}

Acc $=$ Acceptability of Doll Ownership

Imm $=$ Doll Owners as Immoral

Dys $=$ Doll Owners as Dysfunctional

\section{Usage Instructions}

To aid scoring, enter items into surveys in the order presented above. Randomize the order of item presentation to prevent systematic answering.

\section{Scoring Instructions}

Calculate an average (mean) score for each factor. Items with an asterisk (*) should be reverse-scored.

\section{Usage Permissions}

Feel free to use this scale in non-commercial research and practice (with appropriate citation). 